\title{
The Correlational Study of the Influence of Mass Media on One's Self-Satisfaction
}

\author{
Tanat Thanupran ${ }^{1}$, Pimlada Amphichaluay ${ }^{2}$, Phurinut Phlailaharn ${ }^{3}$ \\ ${ }^{1}$ Mahidol University Demonstration School, Thailand ${ }^{2,3}$ Potisarn Pittayakorn School, Thailand
}

Corresponding Author: Tanat Thanupran

\begin{abstract}
As the world has globalized-involving changes in cultures, values, and popularities, people's values have been changing all the time. In recent years, it is undeniable that people have given importance to their "beauty" and "how people judge their looks," which results in the change in beauty standards. One major factor contributing to the change in people's attitudes toward self-satisfaction is "mass media." Nonetheless, there is a lack of evidence to support such a claim to depict between mass media and self-satisfaction. Therefore, this study aims to explore those relationships between the two subjects. A survey using 11 questionnaires for females and 12 questionnaires for males based on a 5-point Likert scale with 165 participants was carried out. The findings of this study showed that mass media influenced selfsatisfaction.

Furthermore, the result showed that mass media and self-satisfaction have a positive correlation. This paper also suggests the readers enhance a positive mindset on their body image to gain more self-worth. This information obtained from the survey also indicates that the readers need to get rid of their negative attitude on their body image or outer appearance in order to be able to feel worthy of self-love and give less importance to their inner beauty or mental health and focus on their appearance.
\end{abstract}

Keywords: beauty standard, mass media, selfsatisfaction, positive mindset and body image

\section{INTRODUCTION}

\subsection{The Definition of Mass Media}

Mass media can be defined as media consisting of appropriate programs, produced by creators or agencies and the audience receives them. According to Oxford dictionaries, it is defined as the different methods of giving information to the audience, for example, through newspapers, television, and radio.

Nowadays, mass media has contributed to many aspects of life. Most of the entire population of every country depends on the mass media and this can be inferred that some people may be affected by mass media. Most teens love watching television and are indirectly affected by antagonist characters in the show they watch (Zaleha, 2010). However, Mass media doesn't always cause positive consequences. There are also negative consequences that affect people's minds, especially youths. As the world changes every day, technology becomes better, therefore, A variety of worldwide information available through the internet, such as news, sending and receiving electronic mail, commerce, entertainment including watching, and more can be accessed (Mokhtar, 2000).

In addition, images and videos in the media such as the internet, television, etc. might be an issue for adults. Since seeing advertisements or videos decreases selfconsciousness in teenagers.

\subsection{The Definition of Body Image (Poon)}

Initially formulated by the German writer-Schilder-in his monograph, body image was regarded as "the picture of the body formed in our mind" (Slade, 1994). It is explicit that these days, as a result of generalization and globalization, people 
usually give value to the beauty of their bodies and their attraction to other people. This perception stems from people's beliefs in their appearances, their feelings on their bodies, and their attitudes toward movement. All of the aforementioned issues can either positively or negatively affect the aspect of our bodies.

Understanding self-worth genuinely, positive body image happens when one admits his appearance, in other words, knowing that an appearance should not be taken into consideration when concerning self-esteem. Whoever has a positive body image is the one who truly accepts and appreciates one's body without any exception. It is literally vital to have a positive body image because it has such a significant impact on our views toward ourselves and our interactions with others; it affects our physical, mental, and social behaviours.

Oppositely, negative body image can occur when one feels dissatisfied with one's appearance. It has been statisticised that in 2020, there was an increasing rate of children who do not like some aspects of their body. (Hosseini, Body image distortion 2021) As people grow older, especially in their teenage years, our body is to be changed due to the changes in hormones, both males and females. Negative body image can become more deep during that period of time. Moreover, our body image can be affected by the ideas and values of our family, acquaintances, education, work, and tradition also. (O'Dea \& Abraham, Improving the body image, eating attitudes, and behaviors of young male and female adolescents: A new educational approach that focuses on self-esteem 2000) Consequently, with negative body image, there is a risk of having a multitude of physically, emotionally, spiritually, or socially unhealthy lifestyles. Associated unhealthy conditions with having a negative attitude toward the body can lead to having a chance of getting various kinds of disorders, social anxiety, low self-worth, muscle dysmorphia-MD, problems with relationships with other people, or even selfharm tendencies. (ApaPsycNet) Thus, it is dramatically vital to tackle and overcome a negative body image.

As having a positive mindset on an appearance is beneficial for us, it is significant to overcome negative body image and boost up our body image to eventually become positive. To have your body image positive, you have to begin with love and respect for your body; this will help you gain more self-confidence-how you feel and think about your body. (Tylka\& Wood-Barcalow, What is and what is not positive body image? Conceptual Foundations and construct definition 2015) Those who have low self-esteem will correlationally lead to having negative body image. To gain more self-esteem, it is needed to positively build up your attitude towards your body. Also, it is important to believe in yourself, try to think that your body can do anything; which means having a positive attitude. This includes trying to avoid thinking of becoming perfectionist, no comparison with others, and avoid criticising one's body. On top of that, raising emotional awareness can help prevent negative body image. (Ata et al., The effects of gender and family, friend, and media influences on eating behaviors and body image during adolescence 2006) This means that it is important to try to handle an emotion when there is an unpredictably upset predicament.

All in all, it is literally essential for us to have a positive body image, as having a positive body image can lead us to having an enhancement of psychological modification; however, negative body image can lead to various kinds of serious disorders to which mass media and changes in life are the main factors, such that it is necessary to overcome such a problem and try to enhance our positive body image.

\subsection{The Definition of Self-Satisfaction and its importance}

Emphasizing the word selfsatisfaction, according to Oxford online 
learner's dictionaries, it is a fact of being satisfied with oneself or their achievements. Moreover, self-satisfaction can also be seen as a subjective evaluation of oneself, environment, and quality of life, which can be influenced by subjective and objective factors (Ilinykh\&Udaltsova, 2016). To be more specific, self-satisfaction grows indifference to people differently.

It is significant to maintain a suitable self-satisfaction because it is undeviatingly related to self-esteem, as Dohnt et al., 2006 mentioned. To be more specific, a study was conducted by Kernis et al., 1993 to prove the hypothesis that the stability of selfesteem affects cognitive and emotional reactions to interpersonal feedback. It was evident that people with greater self-esteem were associated with acceptance and positive sentiments following positive feedback but rejection and defensiveness following negative feedback. On the other hand, instability was irrelevant to positive feedback but to more embryonic defensiveness and greater acceptance of negative feedback for low self-esteem. Moreover, self-satisfaction is curvilinearly associated with the social adjustment and conceptual dimension of ego control. (Block \& Thomas, 1955)

\section{Theoretical Framework; influences of mass media on self-satisfaction}

Nowadays, in a world of technology, it is undeniable that mass media influences self-satisfaction in different perspectives such as body appearances, where people desire to maintain beauty standards and lifestyles. Therefore, when individuals fail to be a part of the above mentioned standards, they grow more selfdissatisfaction, leading to lower self-esteem (Dohnt et al., 2006). Furthermore, research conducted by Knauss et al. concluded that girls showed higher body dissatisfaction, internalization of media ideals, and pressure to achieve it than boys. In addition, it is proved that watching appearance-focused television programs can temporarily antecedent appearance satisfaction (Dohnt et al., 2006). This claim is also supported by another experimental meta-analytic review by Groesz et al., 2001 that satisfaction results more negatively after observing thin media images than after viewing images of average size, plus-size, or inanimate objects.

However, other than mass media, it is also possible that other influences are affecting self-satisfaction, such as cultural differences, parenting styles (Chang 2006), and more.

\section{METHODOLOGY}

The survey involved 165 participants, consisting of 120 women (72.7\%) and 45 men (27.3\%). The data were collected via an anonymous selfadministered questionnaire on the Internet platform. The study was conducted efficiently online during the covid-19 pandemic when all individuals shall isolate themselves from one another. This method requires no contact as well as convenience since anyone can participate from all places. Furthermore, all participants were given insight into the purpose of the study before continuing with their online responses.

This survey was divided into two parts which were questionnaire statements for males and females. The survey was designed to be a 5-point Likert Scale ranging from strongly dissatisfied (scale 1) to strongly satisfied (scale 5).

Regarding the images being used in our survey research, they were used to observe what people usually think of when they first see such images.

For females, the images used in the questionnaire statements consisted of females with different body sizes (thin, normal, overweight), different skin colors (white and dark), different skin surfaces (clear and smooth skin and faces with acne), and different fashion clothing styles (fashionable person and lamestyle person).

Proceed to the next section, where descriptions of all visual media attached to each questionnaire for female participants are provided. 
1.

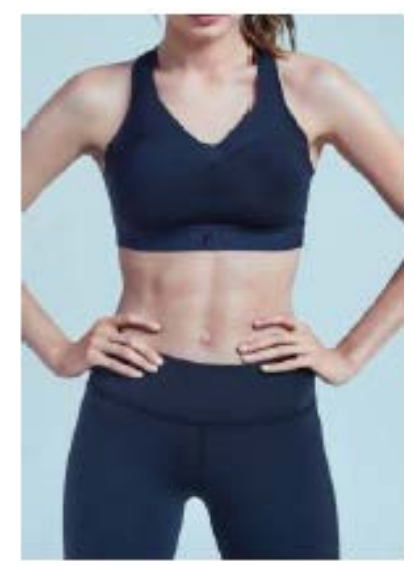

In this image, the model has a strong and slightly masculine body structure, which according to current trends, is an ideal body in a beauty standard.

2.

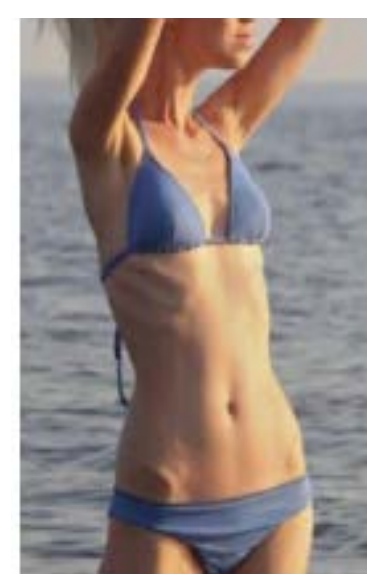

The female model in this image has a rather slender body.

3.

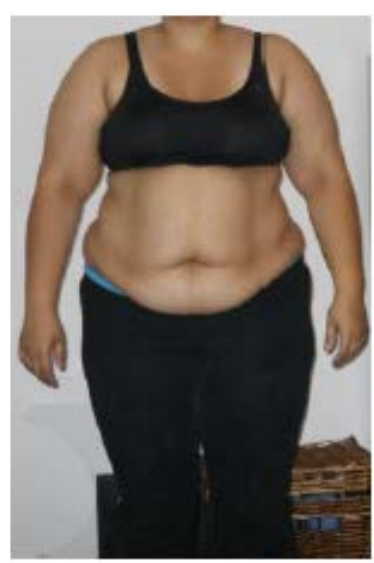

The woman shown in the photograph is overweight.

4. For this part, a commercial of a facial whitening product was provided. This advertisement was once viral as the actress mentioned clearly that "just being white is winning." However, in the end, the commercial was banned as people believe that whether or not we are white, we are all equal. Some think that this publication was trying to promote the misconception of beauty.

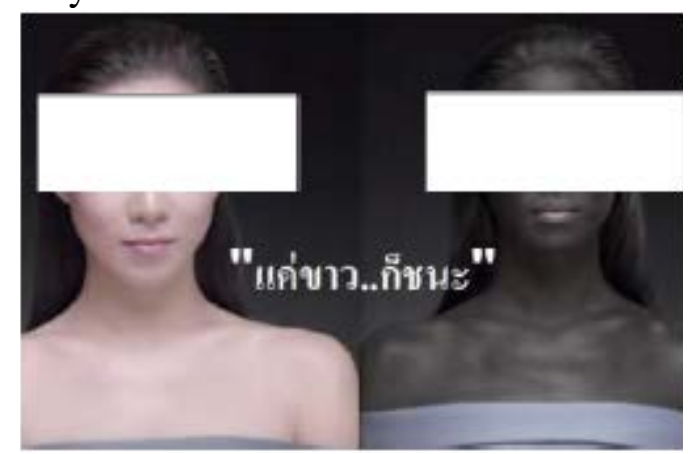

5. One of the music videos by the world's most famous Korean idol girl group, Blackpink, is attached. The members of the band perfectly suit the world's beauty standard from all perspectives. To be more specific, they are tall and have slim bodies. They also have fair skin without acne. In addition, they wore priceful products from world-class designer brands in the project.

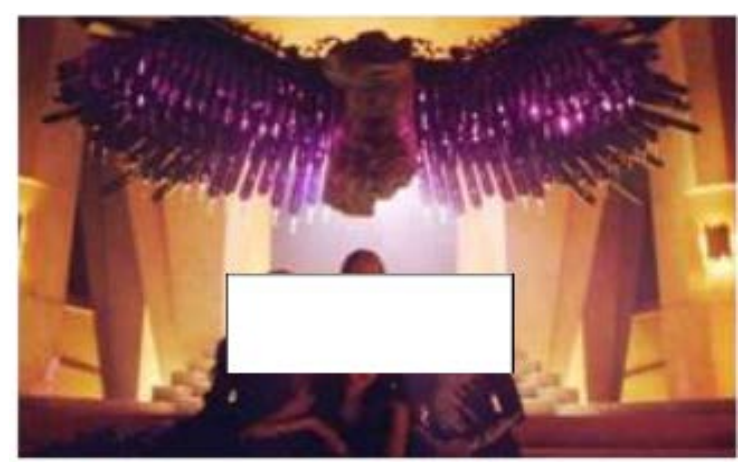

6.

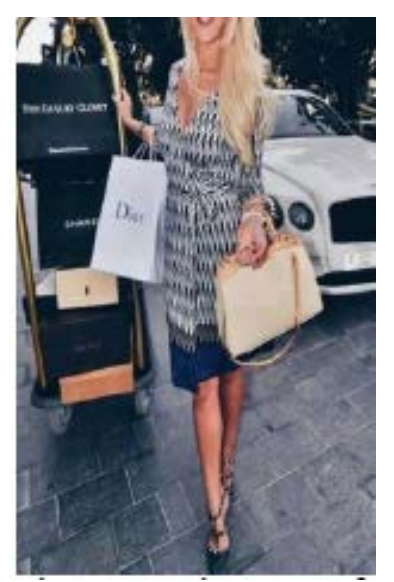

This lady is wearing a fancy dress and holding an expensive handbag while 
owning many more from high-end brands. Furthermore, there is a luxurious car behind her.

7.

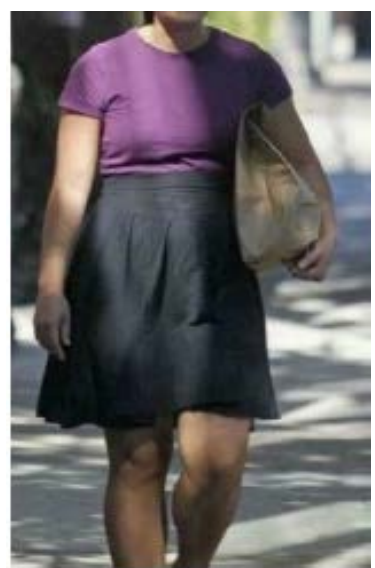

The woman is wearing a casual and simple outfit with an unbranded bag.

8.

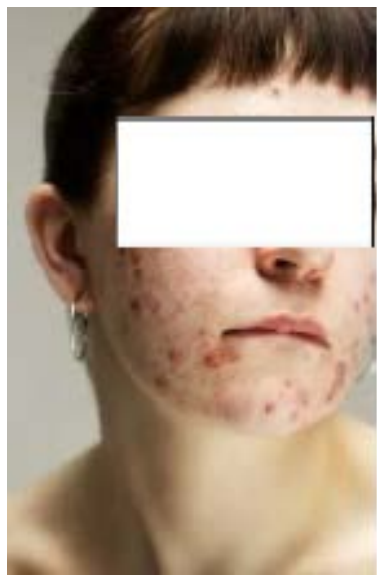

This model has acnes and blemishes surrounding her facial area.

9.

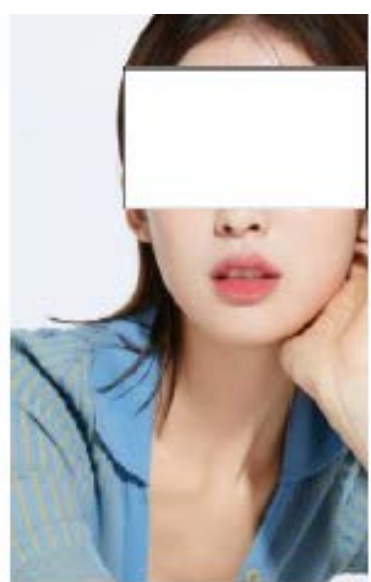

The Korean model has clear acnefree skin. In addition, her skin is smooth and dewy. According to the current beauty standard, this is the perfect skin every girl dreams of.
10.

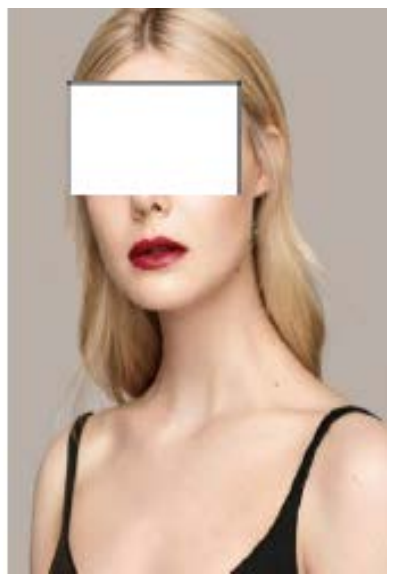

The model in this image has fair, light skin.

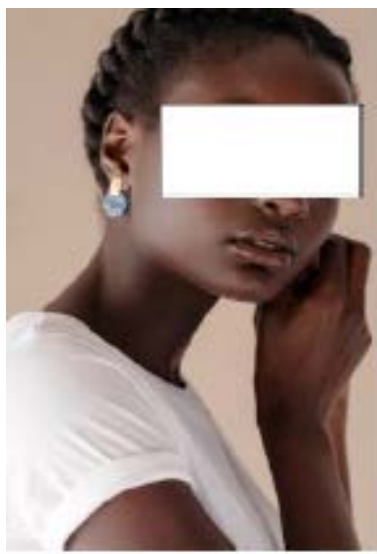

The model in this image has a dark skin color.

Besides, for males, images were the same but might be different in some aspects, consisting of males with different body sizes (thin, normal, muscular, and overweight), different skin colors (white), different skin surfaces (clear and smooth skin, and faces with acne), and different fashion clothing styles (fashionable person and lamestyle person). On top of that, videos were also included in our questionnaires to observe how advertisements and music videos can influence people's minds about their selfsatisfaction.

In this section, descriptions of all visual media attached to each questionnaire for male cooperators are provided. 


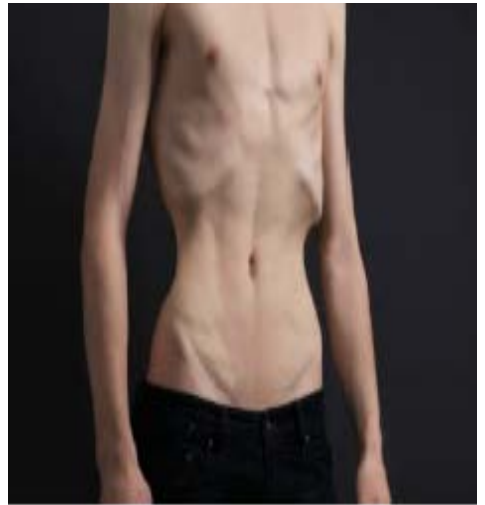

1.This man shown in the picture is underweight.

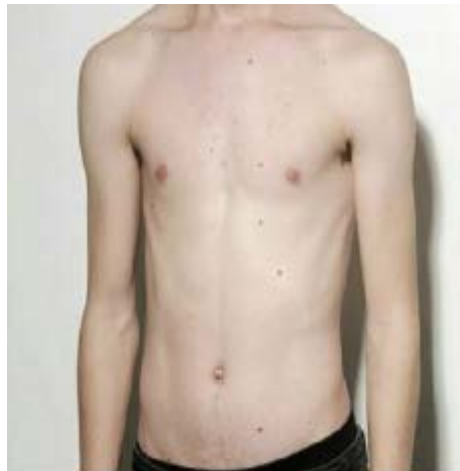

2. The body type of this man is average weight and tall.

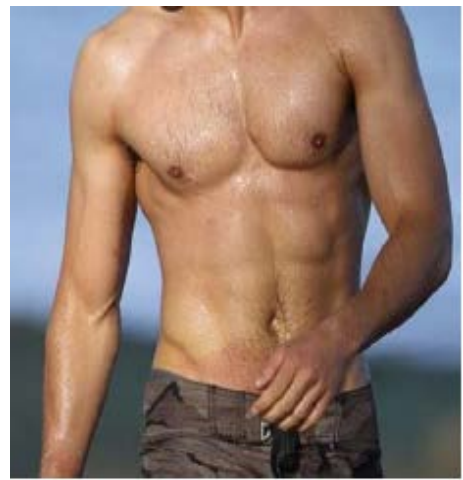

3. The model is firm and the model has a six-pack which most of the males dream of.

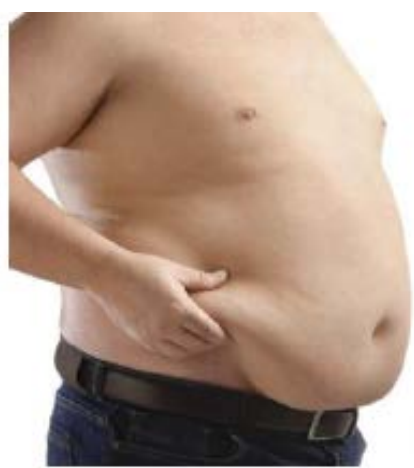

4. The man shown in the photograph is overweight.

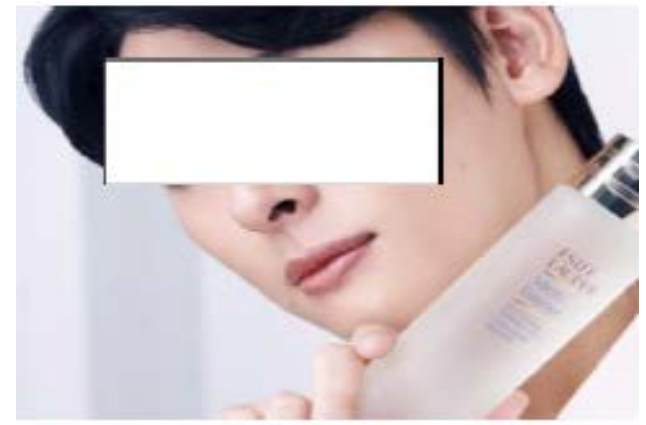

5. The model has flawless skin which fits to the current beauty standards.

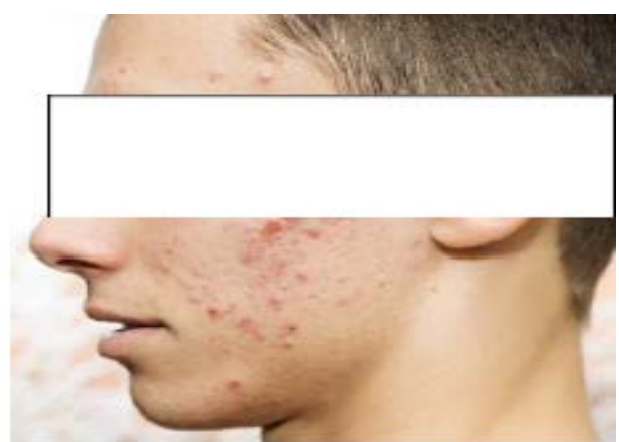

6. The model has acne and redness on his face.

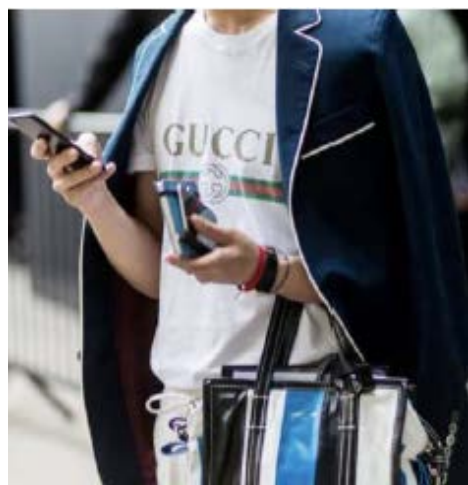

7. This picture refers to a posh lifestyle and people who are fashion-conscious.

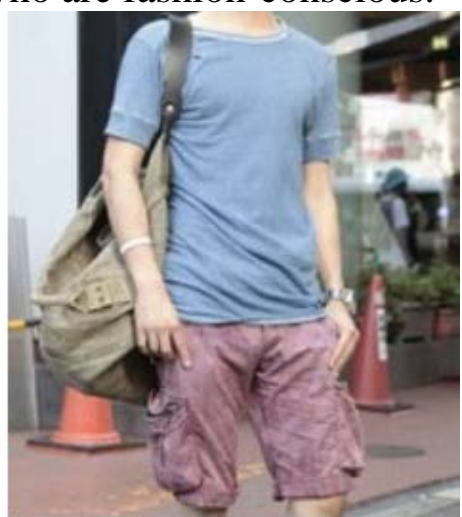

8. The man is wearing a simple outfit and holding a normal bag. 


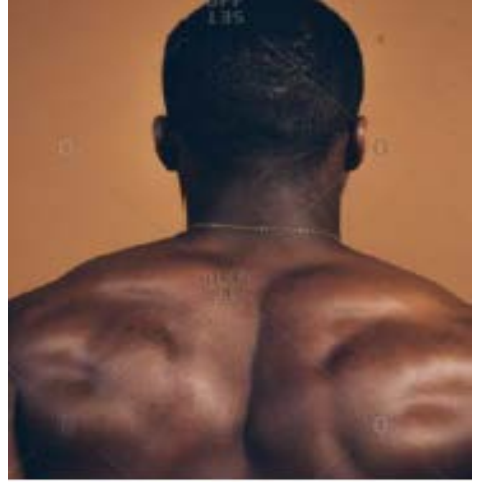

9. The model in this picture has a dark skin colour.

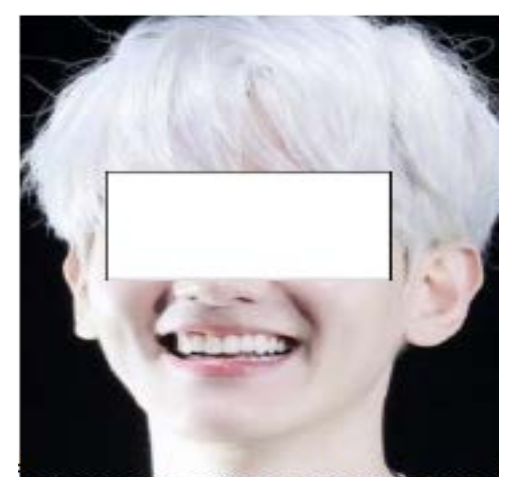

10. The man in this image has fair skin.

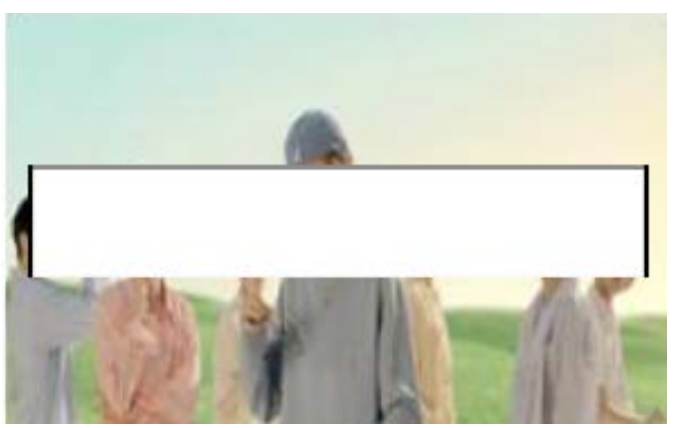

11. Attached here is one of the most famous Korean idol group's music videos. Members in this group used to be named "Most Handsome Man in the World" by the publications which reveals today's beauty standard. They were also the ambassadors of many well-known brands.

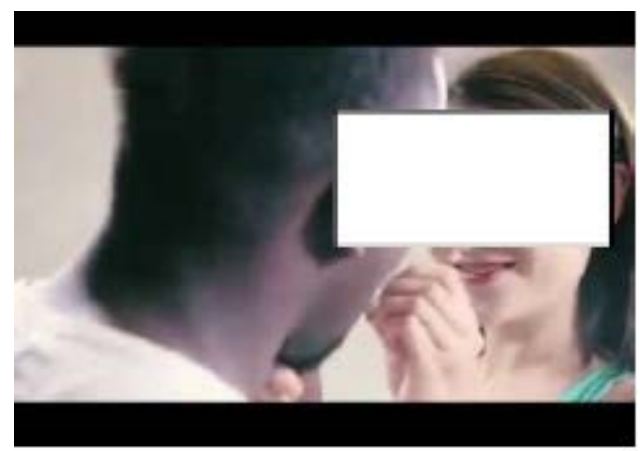

12. A detergent commercial video that aired in China shows a black man being transformed into a fair-skinned man after being stuffed into a washing machine.

\section{RESULTS AND DISCUSSION}

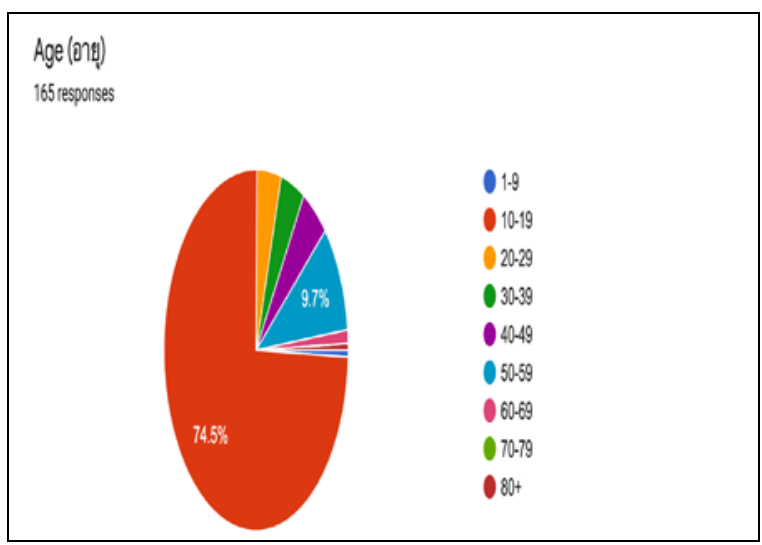

Biological Gender (เพศโดยก่าเนิด)

165 responses

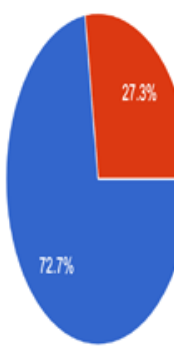

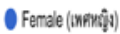

Male (เพตราย)

Regarding the results obtained from the 5-point Likert Scale questionnaires, the data analysis reveals that there is a correlation between mass media and selfsatisfaction; for both males and females. The survey involved 165 participants: ages 1-9 1 participant (0.6\%), ages $10-19123$ participants (74.5\%), ages 20-29 7 participants (4.2\%), ages $30-39 \quad 7$ participants (4.2\%), ages $40-49 \quad 8$ participants (4.8\%), ages 50-59 16 participants (9.7\%), ages 60-69 2 participants (1.2\%) and ages 80 or above 1 participant $(0.6 \%)$. Regarding the biological gender, 120 participants $(72.7 \%)$ are females and 45 participants (27.3\%) are males. 
Tanat Thanupran et.al. The correlational study of the influence of mass media on one's self-satisfaction
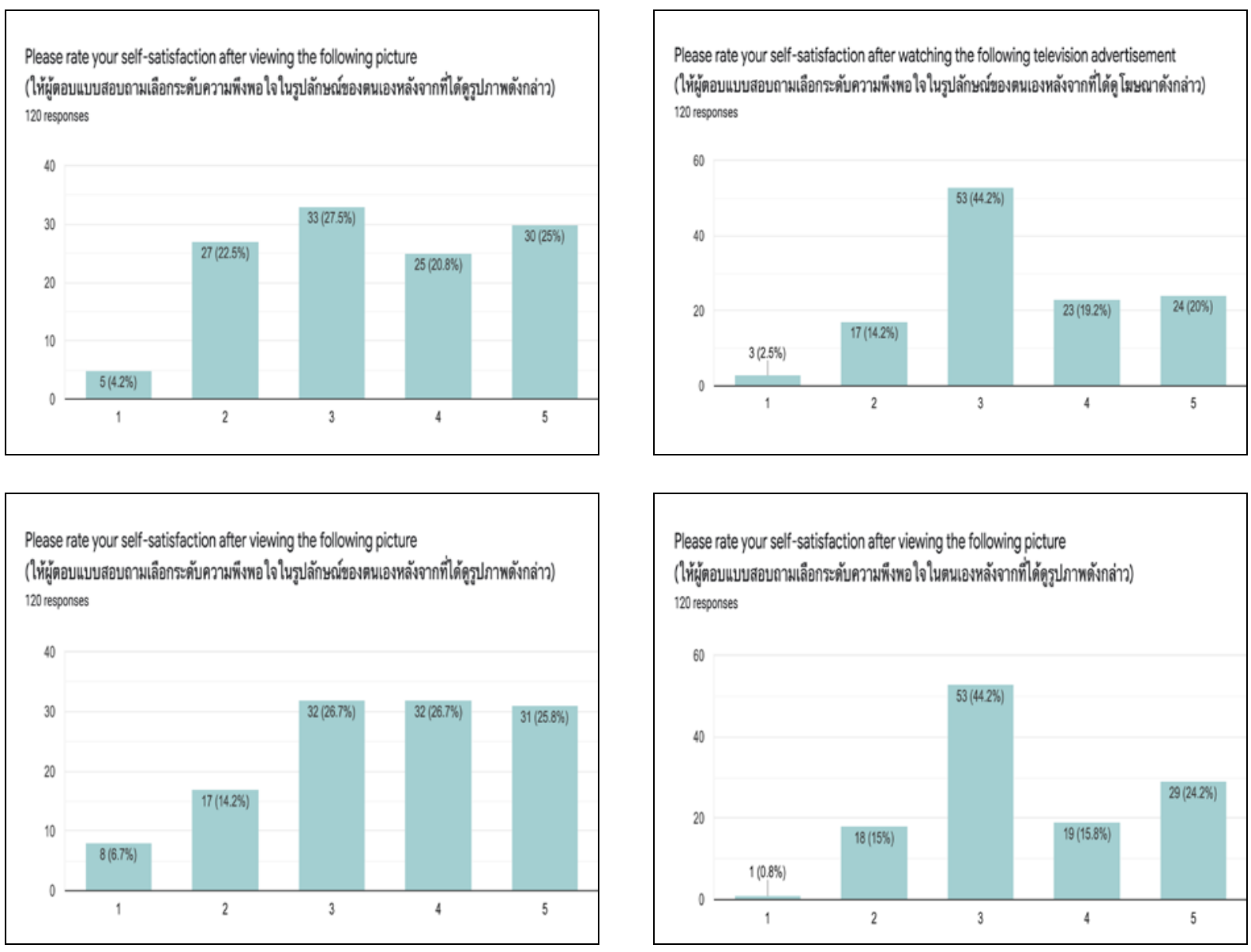

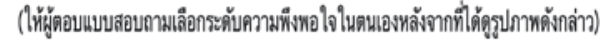
120 responses
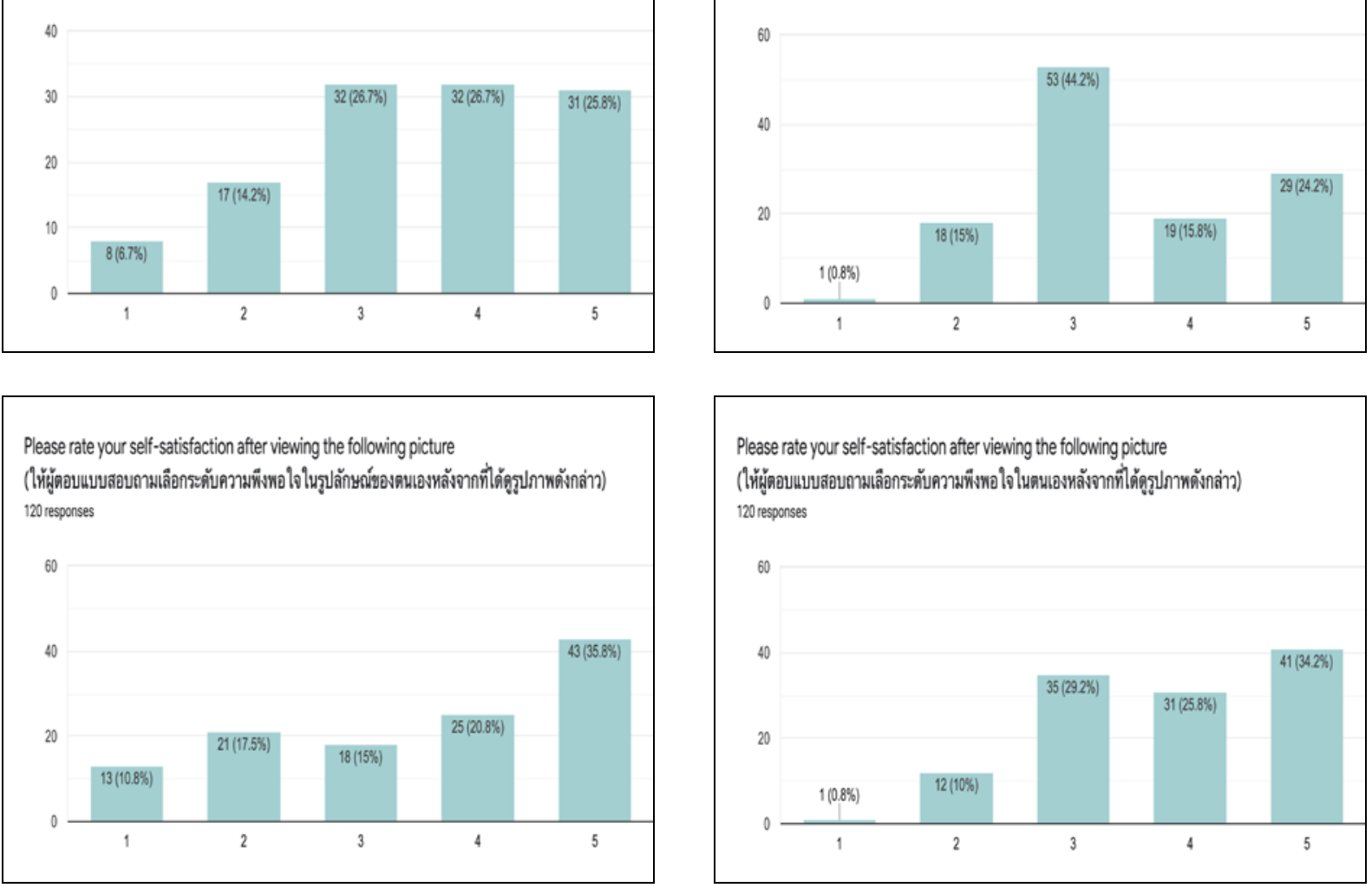

(ให้ผู้ตอบแบบสอบถามเลือกระดับความพึงพอใจในตนเองหลังจากที่ได้ดูรูปภาพดังกล่าว) 120 responses
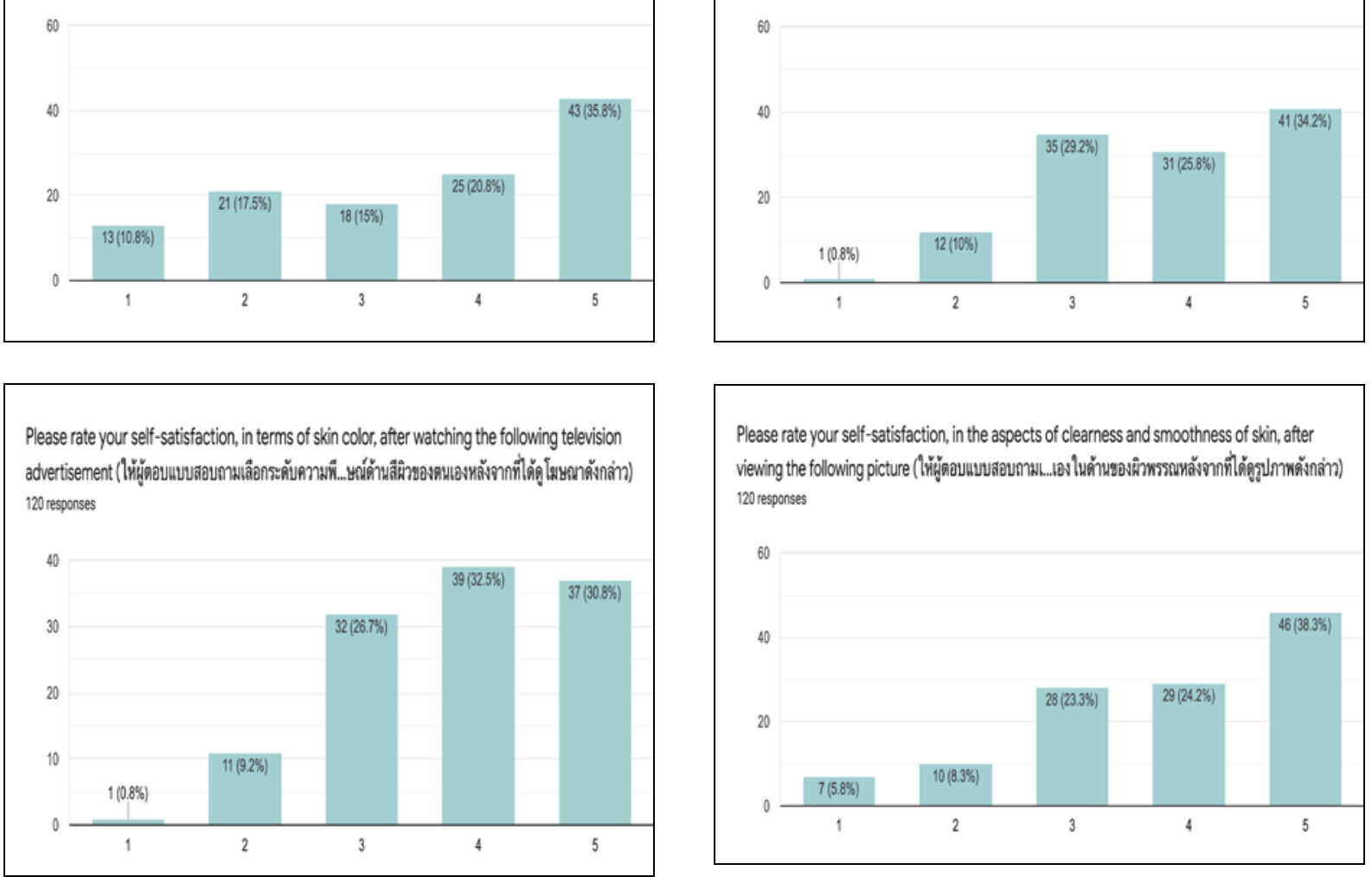

Please rate your self-satisfaction, in the aspects of clearness and smoothness of skin, after viewing the following picture (ให้ผู้ตอบแบบสอบถามเ...องในด้านของผิวพรรณหลังจากที่ได้ดูปปภาพดังกล่าว) 120 responses

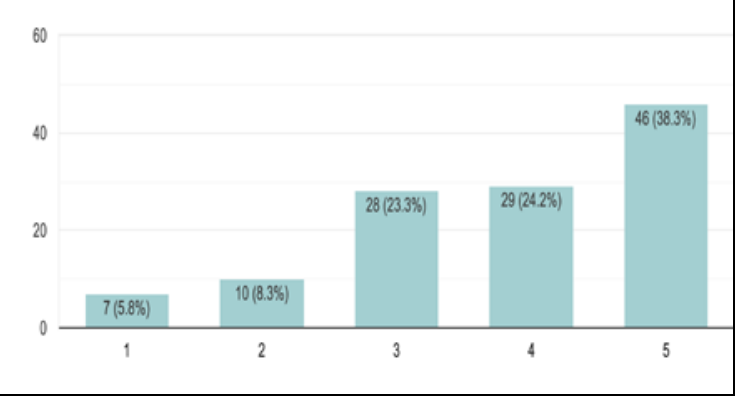



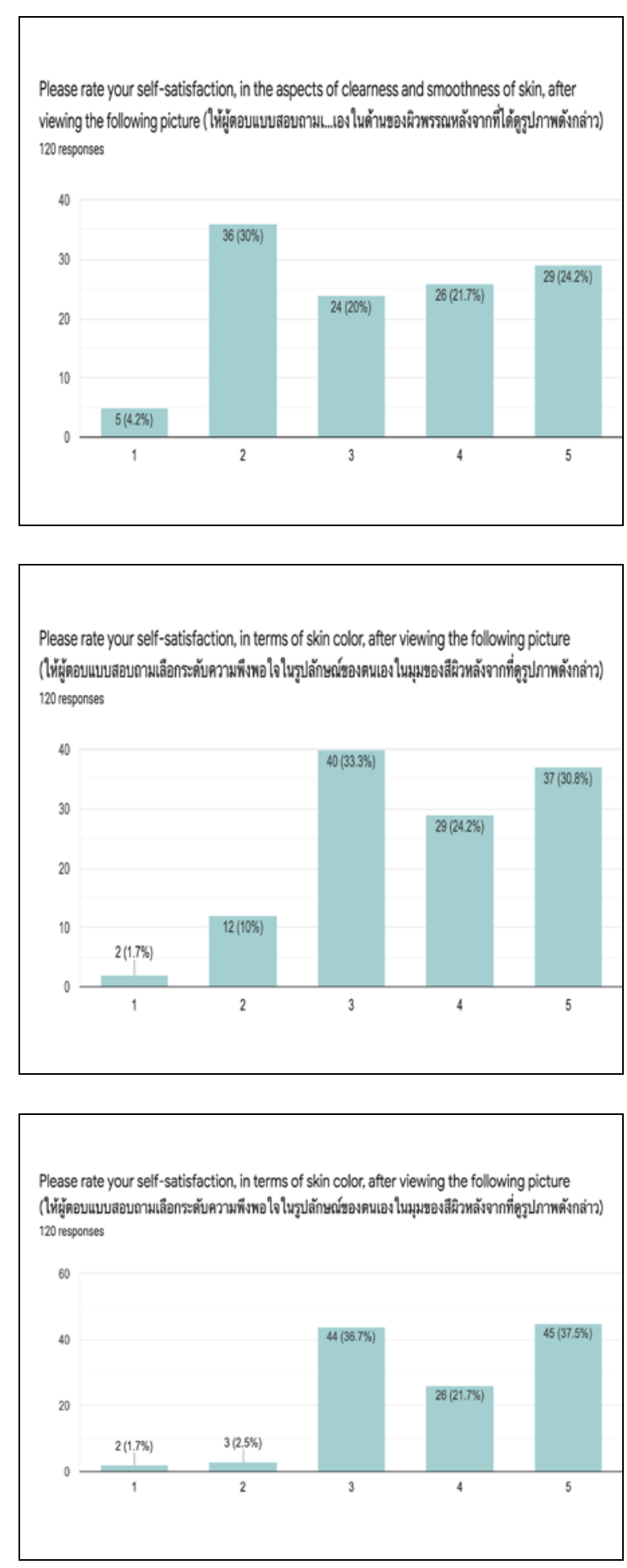

According to the bar charts, specifically focusing on body sizes, some of the females were still satisfied with their body when they saw an image of a strong model whose body is slightly masculine, some of them felt nothing and some felt dissatisfied with their body, which is valued by most of the people in this generation currently. This may vary depending on people's attitude. (see figure 1) Coming to the next image, (see figure 2) a female model with a slender body, some of the participants felt nothing and some feel satisfied with their body and for an image of an overweight woman, (see figure 3) most of the participants felt satisfied with their body. For the videos attached to the questionnaires, some of the participants felt nothing when they saw an advertisement of a whitening product and some others felt satisfied with their body. (see figure 4) This may vary due to the participants in which most of the participants might be white in their skin. For the music video of the famous Korean idol group, most of the participants felt nothing when they watched this music video, while some others felt satisfied with their body. (see figure 5) Focusing on fashion clothing styles, for an image of the lady wearing a fancy dress in a luxurious lifestyle, most of the participants felt nothing while some others felt satisfied with their body. (see figure 6) Oppositely, when they saw an image of a woman wearing a casual outfit along with an unbranded bag, they felt satisfied with themselves and some others felt nothing. (see figure 7) Besides, focusing on skin surface, when participants saw an image of the model with acnes and blemishes, participants felt satisfied with their appearance (see figure 8) while most of the participants felt dissatisfied with their face when they saw an image of the Korean model who has clear acne-free skin which is what current beauty standard is looking for. (see figure 9) Lastly, for an issue of the skin color, some of the participants felt nothing and some others felt satisfied with their skin color, (see figure 10) as same as an image of participants with a dark skin color that some of the participants felt nothing and some others felt satisfied with their body. (see figure 11) This can be concluded that selfsatisfaction may not be affected by the skin color for females. 
Tanat Thanupran et.al. The correlational study of the influence of mass media on one's self-satisfaction
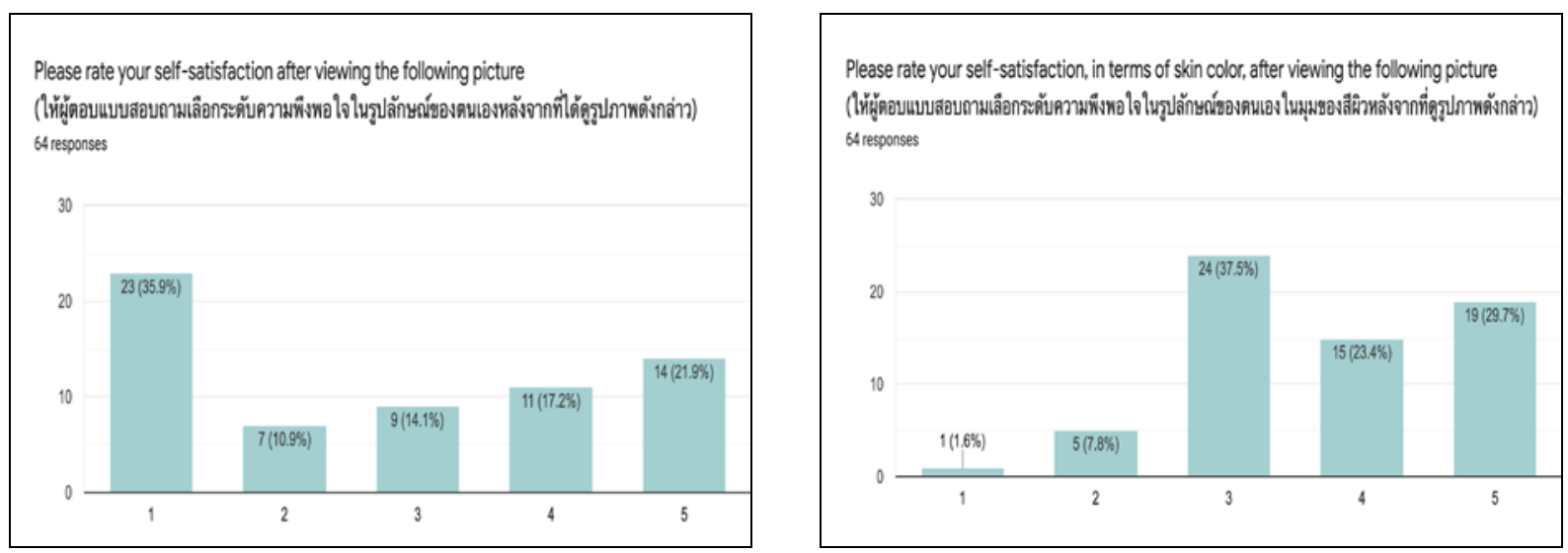

\section{Please rate your self-satisfaction after viewing the following picture \\ (ให้ผู้ตอบแบบสอบถามเลือกระดับความพึงพอใจในรูปลักษณ์ของตนเองหลังจากที่ได้ดูรูปภาพดังกล่าว)} 64 responses

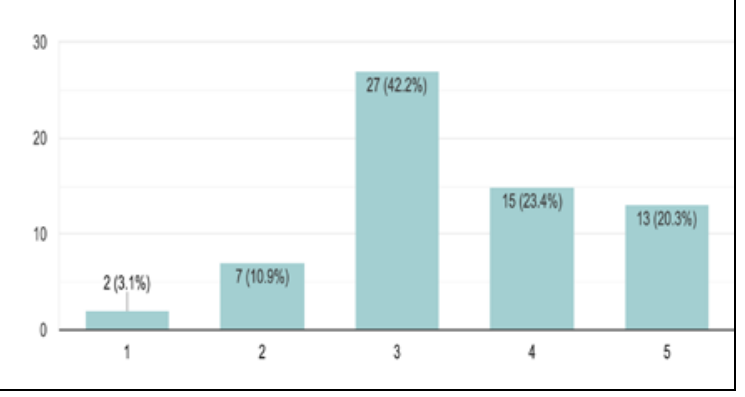

Please rate your self-satisfaction, in terms of skin color, after viewing the following picture

(ให้ผู้ตอบแบบสอบถามเลือกระดับความพืงพอใจในรูปล้กษณ์ซองตนเองในมุมของสีผิวหลังจากที่ดูรปภาพดังกล่าว) 64 responses
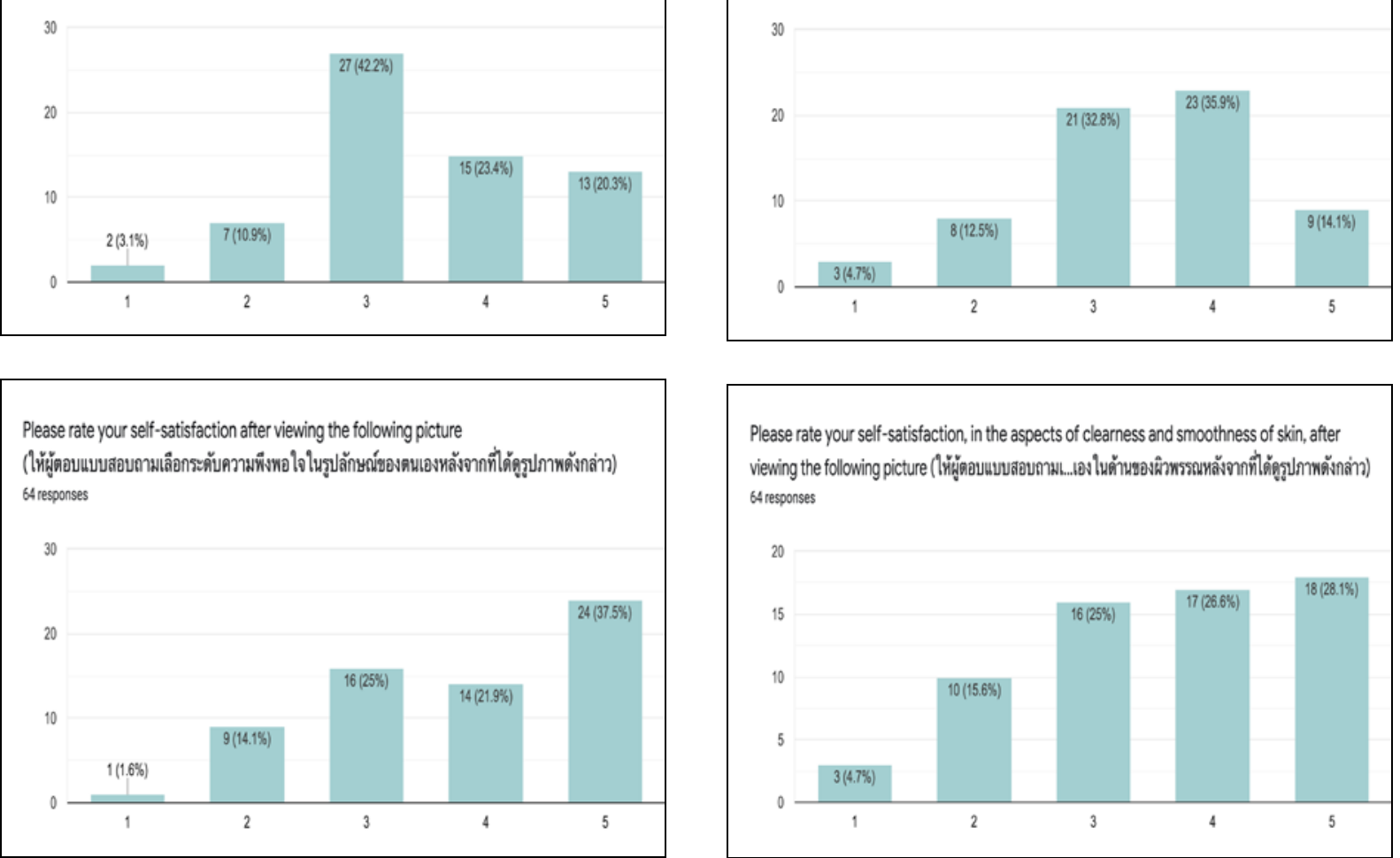

Please rate your self-satisfaction, in the aspects of clearness and smoothness of skin, atter viewing the following picture (ให้ผู้ดอบแบบสอบถามเ...องในด้านของผิวพรรณหล้งจากที่ได้ดูปภาพดังกล่าว) 64 responses

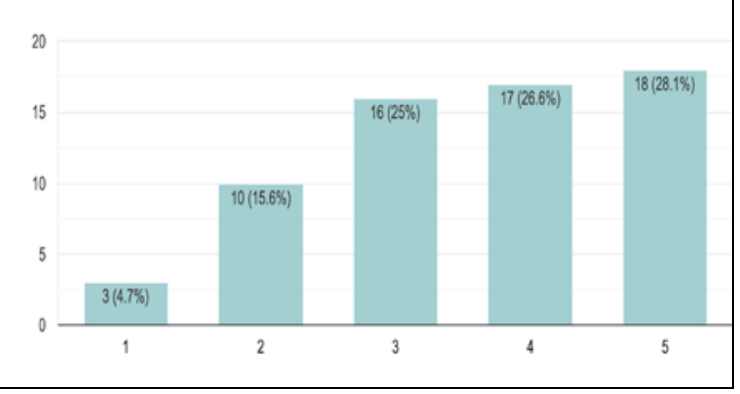

Please rate your self-satisfaction after viewing the following picture

(ให้ผู้ตอบแบบสอบถามเลือกระดับความพึงพอใจในรูปลักษณ์ของดนเองหลังจากที่ได้ดูรูปภาพดังกล่าว) 64 responses

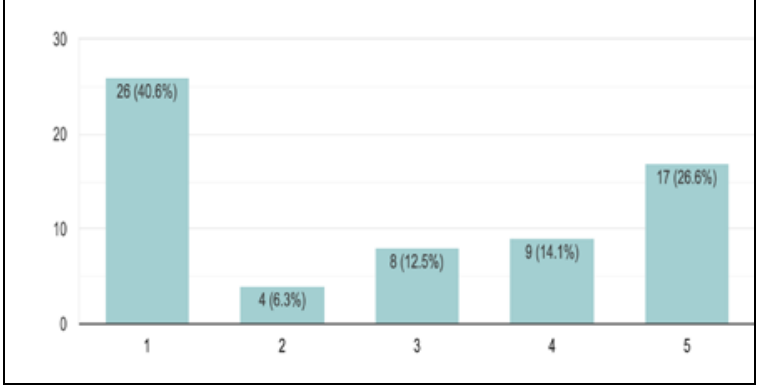

Please rate your self-satisfaction, in the aspects of clearness and smoothness of skin, after viewing the following picture (ให้ผู้ตอบแบบสอบถามเ...เองในด้านของผิวพรรณหลังจากที่ได้ถูปูกาพดังกล่าว) 64 responses

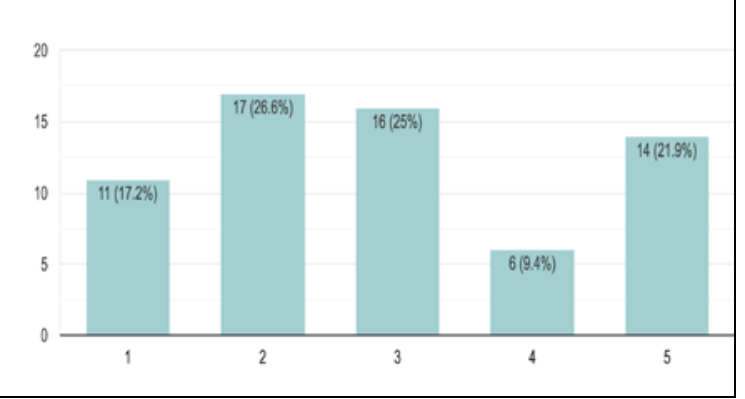



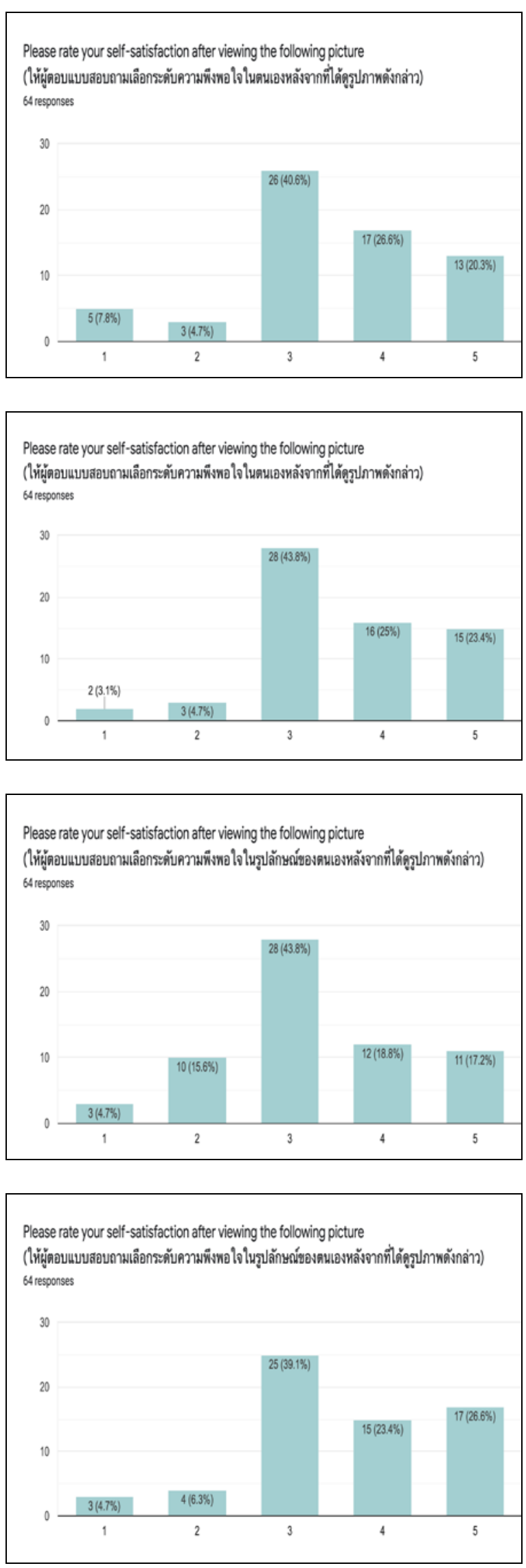

According to the bar charts, focusing on body shapes, most of the participants who are males are not content with their body after seeing an image of a man who is underweight while some of them felt the same with their body (see figure 1). Coming to the next picture, a man with average weight and tall, the vast majority of people felt content with their appearance but some of them felt the same (figure 2). Proceeding to the next picture, a man who is firm and has a six-pack, most of the participants felt satisfied with their body after seeing the picture (figure 3). Continuing to the next picture, a man who is overweight, most people felt unsatisfied with their body after seeing the picture (figure 4). The next picture is of a man who is fair-skinned. The number of people who felt the same and felt content with their body is quite close (figure 5). Proceeding to the next picture, a man who has a dark skin color. People felt satisfied with their skin color after seeing the picture (figure 6). Focusing on the skin surface, most of the participants felt satisfied with their facial area after seeing the model has flawless skin which fits the current beauty standards (Figure 7). Most of the participants felt dissatisfied with their facial area after seeing the model that has acne and redness on his face (Figure 8). Continuing with the fashion clothing styles, Most of the participants felt satisfied with their lifestyle but there were some people who felt nothing and fewer people felt dissatisfied with their lifestyle after seeing the picture of a man wearing a simple outfit and holding a normal bag (figure 9). The vast majority of participants felt the same and some of them felt nothing after seeing a man with a posh lifestyle (figure 10). Coming to the attached K-Pop video, people felt nothing after watching the music video, while some people felt satisfied with their bodies (figure 11). Lastly, focusing on the commercial video, most of the participants felt satisfied with their skin color after watching the video and $39.1 \%$ felt the same after watching the video (figure 12). 


\section{CONCLUSION}

Emphasizing this study investigates the relationships between the levels of selfsatisfaction (a subjective evaluation of oneself, environment, and quality of life) and mass media influences. It provides empirical evidence to support statistical links based on 165 respondents, including 45 males and 120 females. The responses after viewing the media attached to each item vary. It shows that people care more about a particular aspect. To be more specific, participants' self-satisfaction tends to be affected and sensitive to skin's smoothness while not reacting much to skin color. The result is understandable as people experience different cultures and grow up differently; therefore, contents affecting their satisfaction may differ.

\section{Conflict of Interest: None}

\section{REFERENCES}

1. 25 KPOP boys that rock white hair!:KpopChingu. KPOP CHINGU |. (2020, March 13). Retrieved November 25, 2021,

fromhttps://kpopchingu.com/2020/03/13/25kpop-boys-that-rock-white-hair/.

2. 292804413275631165: Makeup Looks, Elle Fanning, Dakota and elle fanning. Pinterest. (2021, August 5). Retrieved November 25, 2021,

fromhttps://www.pinterest.com/pin/8110702 14135841440/.

3. American Psychological Association. (n.d.). ApaPsycNet. American Psychological Association. Retrieved November 21, 2021, fromhttps://psycnet.apa.org/record/201557083-001.

4. American Psychological Association. (n.d.). ApaPsycNet. American Psychological Association. Retrieved November 25, 2021, fromhttps://psycnet.apa.org/record/195604178-001.

5. American Psychological Association. (n.d.). ApaPsycNet. American Psychological Association. Retrieved November 25, 2021, fromhttps://psycnet.apa.org/record/199417494-001.

6. Ata, R. N., Ludden, A. B., \&Lally, M. M. (2006, December 16). The effects of gender and family, friend, and media influences on eating behaviors and body image during adolescence. Journal of Youth and Adolescence. Retrieved November 21, 2021, fromhttps://link.springer.com/article/10.100 7\%2Fs10964-006-9159-x.

7. Best Beach Bodies. Men's Health. (2019, February 25). Retrieved November 25, 2021,

fromhttps://www.menshealth.com/fitness/a1 9546620/best-summer-bodies/.

8. Black Man in Chains on offset. OFFSET. (n.d.). Retrieved November 25, 2021, fromhttps://www.offset.com/search/black+ man+in+chains.

9. BTS (방란소년단) 'dynamite' official MV. YouTube. (2020, August 20). Retrieved November 25, 2021, fromhttps://youtu.be/gdZLi9oWNZg.

10. Chang, M. (2007). Cultural differences in parenting styles and their effects on teens' self-esteem, perceived parental relationship satisfaction, and self-satisfaction (Doctoral dissertation, Carnegie Mellon University).

11. Cleyde Loretto on Instagram: "https://www.instagram.com/p $\quad \ldots \quad$ (n.d.). Retrieved November 25, 2021, fromhttps://www.instagram.com/p/CQ99Y4 SjHik/.

12. Épinglé sur celebs. Pinterest. (n.d.). Retrieved November 25, 2021, fromhttps://www.pinterest.com/pin/8442842 61388470631/.

13. Google. (n.d.). Google. Retrieved November 25, 2021, fromhttps://www.google.co.th/search?q=ano rexic\%2Bgirl\%2Bin\%2Bbikini\&hl=th\&sxsr $\mathrm{f}=$ ALeKk01FXIV1LVndGFqn7m4muAb2lr luRQ\%3A1627899178292\&source=lnms\&t bm=isch\&sa=X\&ved=2ahUKEwih3oGCjZ LyAhWK3jgGHaUhAAwQ_AUoAXoECA EQAw\&biw $=1116 \&$ bih $=540 \#$ imgrc $=7 x k 7 \mathrm{R}$ YaSu67oYM.

14. Google. (n.d.). Google. Retrieved November 25, 2021, fromhttps://www.google.co.th/search?hl=th \&tbs=simg\%3ACAQS_1wEJxGLSSUZr3Y ca8wELELCMpwgaOgo4CAQSFKMiyCD pOZQDtz6lOOYK3TS0GcMeGhr_1ZvGK ROpab01Z8-

ColZHvDL0soZGt3jYXtSAFMAQMCxCO rv4IGgoKCAgBEgRqXrOxDAsQne3BCRq TAQoaCgdtaWRyaWZm2qWI9gMLCgkvb S8wOTU4dGcKHAoJZm9yIHdvbWVu2q WI9gMLCgkvYS9jMDZ2YjkKHQoKc3dl 
YXRwYW50c9qliPYDCwoJL20vMDU2Zj J3ChgKBXRpZ2h02qWI9gMLCgkvYS9m MWxjZnkKHgoLbG93IHdhaXNOZWTapY j2AwsKCS9hLzlrd2g1Nww\&sxsrf=ALeKk 021G7HLsx0FLd3Zd0BnLJmWkWb2Tg\% 3A1627811726389\&q=54\%2Bpercent\%2B body\%2Bfat\&tbm=isch\&sa $=X \& v e d=2 a h U$ KEwiZnNmdx4_yAhXuDaYKHcm6CkkQ wg4oAHoECAEQMQ\&biw=1440\&bih=78 9\&dpr=2\#imgrc=j0ICcUCLBoTKPM.

15. Google. (n.d.). Google. Retrieved November 25, 2021, fromhttps://www.google.co.th/search?hl=th \&sxsrf=ALeKk03k2e58OMuZICmvdYaVK _pwOmZ4dg\%3A1627899528268\&q=soph ie\%2Bharris\%2Btaylor\%2Bepidermis\&tbm $=$ isch\&source=iu\&ictx $=1 \&$ tbs $=$ simg $\% 3 \mathrm{AC}$ AEShQIJ61pjEOiw2mUa-

QELELCMpwgaOgo4CAQSFPsiyTbFGsY FjzOPG_1IFzgeFGaQLGhoZEMmpz5NVIj X4KzYmj1JG381bUI8iCe8SByAFMAQM CxCOrv4IGgoKCAgBEgSNp77MDAsQne 3BCRqZAQocCglmb3IgYWR1bHTapYj2A wsKCS9hLzkzY3dfeQoiCg9iYXJIY2hlc3R lZG5lc3PapYj2AwsKCS9tLzBkbTZkbAog Cg1ubyBleHByZXNzaW9u2qWI9gMLCgk vai85X2JocG4KGgoHZm9yIG1lbtqliPYDC woJL2EvNTZ6ZmNyChcKBHVnbHnapYj 2AwsKCS9hL2IwZGdwMww\&fir=2Sk_Xl KtQhT3zM\%252C5VoOgCbSBf3J9M\%25 2C_\&vet=1\&usg=AI4_-

kR7mVzbLb3VMV_TC0A5T1x4J_IHTg\&s $\mathrm{a}=$ X\&ved=2ahUKEwiV1_KojpLyAhVFBK YKHTvgDIgQ9QF6BAgHEAE\&biw=945 \&bih=684\#imgrc $=2 S k \_X l K t Q h T 3 z M$.

16. Google. (n.d.). Google. Retrieved November 25, 2021, from https://www.google.co.th/search?hl=th\&sxs rf=ALeKk03sEHlNg3xZvjZfTr8IitW4FMib NA\%3A1627899614283\&q=rich\%2Bkids \%2Bin\%2Bdubai\&tbm=isch\&source=iu\&ic $\mathrm{t} x=1 \& \mathrm{tbs}=$ simg\%3ACAES-

wEJJ2PngcQumxEa7wELELCMpwgaOgo4 CAQSFJoM0jmLCJzjkEMslnyjDD6MwGh qYci-

CmTuiBMGk5B2_16G0FU7FBN6VcnnQT RyAFMAQMCxCOrv4IGgoKCAgBEgR8Y WGqDAsQne3BCRqPAQoeCgtyb2xscy1yb 3ljZdqliPYDCwoJL20vMGRtbmoyChYKB GNpdHnapYj2AwoKCC9tLzAxbjMyChY KBHRyZWXapYj2AwoKCC9tLzA3ajdyC hgKBWJsb25k2qWI9gMLCgkvbS8wMjk0 amIKIwoQaGlnaC1oZWVsZWQgc2hvZdql iPYDCwoJL20vMDZrMm1iDA\&fir=AI4o Kdp491gEhM\%252CQ8_Lzd-
82RCPrM\%252C_\&vet=1\&usg=AI4_kSFOVt235LaxNN0k_mytHAEnA1YIw\&s $\mathrm{a}=$ X\&ved=2ahUKEwiTxfTRjpLyAhVQE6 YKHdo9DNkQ9QF6BAgKEAE\&biw=945 \&bih=684\&dpr=2\#imgrc $=$ AI4oKdp491gEh M.

17. Google. (n.d.). Google. Retrieved November 25, 2021, fromhttps://www.google.co.th/search?sa=G \&hl=th\&sxsrf $=$ ALeKk009xY7Oz4kib7tCkcM6Lgp0zLMgQ\%3A162789964650 6\&q=priscilla\%2Bchan\&tbm=isch\&source =iu\&ictx $=1 \&$ tbs $=$ simg\%3ACAES9AEJCtn 7RZBLo54a6AELELCMpwgaOwo5CAQS FLEV_1zbcKcoOsA6WKM4HpyDRN6orG htRGzGCU89mQc23WCyKTJV1NmLytbc eCG5xibAgBTAEDAsQjq7-

CBoKCggIARIEUN_1A5AwLEJ3twQkah wEKFwoEbGFkedqliPYDCwoJL20vMDJw a2I4ChgKBWFua2xl2qWI9gMLCgkvbS8w MXhsdnkKGAoFdGlnaHTapYj2AwsKCS9 hL2YxbGNmeQodCgpiZWxvdyBrbmVl2q WI9gMLCgkvYS81X3BfamMKGQoGc3R yZWV02qWI9gMLCgkvbS8wMWM4YnI M\&fir=wyyB5sYmh2ECjM\%252C7hvVK Us4WsEryM\%252C_\&vet=1\&usg=AI4_kQJHynaaeDTaFGZ3d7EO3nznHIqfA\&ve d=2ahUKEwiqp6PhjpLyAhUSvpQKHQlaB K0Q9QF6BAgIEAE\&biw $=945 \&$ bih $=684 \# i$ mgrc $=$ wyyB5sYmh2ECjM\&imgdii $=j L e 2 w s$ $\mathrm{nOl} 2 \mathrm{Fl} 2 \mathrm{M}$.

18. Groesz, L. M., Levine, M. P., \&Murnen, S. K. (2001, December 26). The effect of experimental presentation of thin media images on body satisfaction: A meta-analytic review. Wiley Online Library. Retrieved November 25, 2021, fromhttps://onlinelibrary.wiley.com/doi/abs/ 10.1002/eat.10005.

19. Haykirdi, Bluecinema, Dusanpetkovic, Drazen_, Metamorworks, Jeremyiswild, PeopleImages, GoodLifeStudio, Spyarm, Studio, M., Monkeybusinessimages, SanyaSM, Juanmonino, House, I. C., Syldavia, turk_stock_photographer, Ghosh, A., Mitchell, D., Ridofranz,... Familylifestyle. (n.d.). Pimple man pictures, images and Stock Photos. iStock. Retrieved November 25, 2021, fromhttps://www.istockphoto.com/photos/pi mple-man.

20. Hosseini, S. A. (2021, September 9). Body image distortion. StatPearls [Internet]. Retrieved November 21, 2021, 
fromhttps://www.ncbi.nlm.nih.gov/books/N BK546582/.

https://www.google.com/url?sa=i\&url=https \%3A\%2F\%2Fwww.quora.com\%2FDoskinny-guys-look-more-handsome-withmuscles\&psig=AOvVaw218cUeQhYAMje n0k_fSSyn\&ust $=1627893975835000 \&$ sour ce=images\&cd=vfe\&ved=0CAwQjhxqFwo TCOC7gua3j_ICFQAAAAAdAAAAABAs

21. Knauss, C., Paxton, S. J., \&Alsaker, F. D. (2007, September 21). Relationships amongst body dissatisfaction, internalisation of the media body ideal and perceived pressure from media in adolescent girls and boys. Body Image. Retrieved November 25, 2021, from https://www.sciencedirect.com/science/artic le/abs/pii/S1740144507000721.

22. M;, D. H. T. (n.d.). The contribution of Peer and media influences to the development of body satisfaction and self-esteem in young girls: A prospective study. Developmental psychology. Retrieved November 25, 2021, fromhttps://pubmed.ncbi.nlm.nih.gov/16953 697/.

23. Nikolay. (2021, March 11). "can skinny guys get big?" is the wrong question to ask. Mario Tomic. Retrieved November 25, 2021, fromhttps://www.tomic.com/skinnyguy-muscle-gain/.

24. O'Dea, J. A., \& Abraham, S. (2000, May 2). Improving the body image, eating attitudes, and behaviors of young male and female adolescents: A new educational approach that focuses on self-esteem. Wiley Online Library. Retrieved November 21, 2021, fromhttps://onlinelibrary.wiley.com/doi/abs/ 10.1002/(SICI)1098-108X (200007) 28:1\% 3C43::AID-EAT6\%3E3.0.CO;2-D.

25. Pin on beauty hairstyles. Pinterest. (n.d.). Retrieved November 25, 2021, from https://www.pinterest.com/pin/3265110417 33230535/.

26. Pinterest. (n.d.). Retrieved November 25, 2021, fromhttps://www.pinterest.com/pin/8015006 8359143591/.

27. Racism in a Chinese laundry detergent advertisement. YouTube. (2016, May 27). Retrieved November 25, 2021, fromhttps://youtu.be/Few8kJ0zfnY.

28. Rahman, A. (2021, April 14). IPARK: Automated smart parking system. International Journal of Advances in Applied Sciences (IJAAS). Retrieved
November

25 , 2021, fromhttps://www.academia.edu/46860655/i

Park_automated_smart_parking_system.

29. Ratswd Working Paper Series KONSORTSWD / Ratswd. (n.d.). Retrieved November 25, 2021, fromhttps://www.konsortswd.de/wpcontent/uploads/RatSWD_WP_111.pdf.

30. Self-satisfaction. self-satisfaction noun Definition, pictures, pronunciation and usage notes | Oxford Advanced Learner's Dictionary at OxfordLearnersDictionaries.com. (n.d.). Retrieved November 25, 2021, fromhttps://www.oxfordlearnersdictionaries. com/definition/english/selfsatisfaction?q=self\%2Bsatisfaction\%2B.

31. Shorr, T., \& Taryn Shorr Writer. (2021, November 18). Korean male fashion trends in 2021. Next Luxury. Retrieved November 25, 2021, fromhttps://nextluxury.com/mensstyle-and-fashion/korean-male-fashiontrends/.

32. Slade, P. D. (2002, May 24). What is body image? Behaviour Research and Therapy. Retrieved November 25, 2021, fromhttps://www.sciencedirect.com/science/ article/abs/pii/0005796794901368.

33. Topless overweight man holding body fat by Science Photo Library. Pixels. (n.d.). Retrieved November 25, 2021, from https://pixels.com/featured/1-toplessoverweight-man-holding-body-fat-sciencephoto-library.html.

34. Tylka, T. L., \& Wood-Barcalow, N. L. (2015, April 25). What is and what is not positive body image? Conceptual Foundations and construct definition. Body Image. Retrieved November 21, 2021, fromhttps://www.sciencedirect.com/science/ article/abs/pii/S1740144515000388.

35. YouTube. (2020, June 26). Blackpink 'How You Like That' M/V. YouTube. Retrieved November 25, 2021, fromhttps://www.youtube.com/watch?v=io Nng23DkIM.

36. YouTube. (n.d.). YouTube. Retrieved November 25, 2021, from https://www.youtube.com/watch?v=WAXO upabYOo.

37. ปั้นจั่นปรมะเผยเหตุอันฟอลโลว์ไอจีดาราทุกค นแย้มเตรียมบวชธ.ค.นี้. www.thairath.co.th. (2019, October 24). Retrieved November 25, 2021, from 
https://www.thairath.co.th/entertain/news/16 89588.

38. สงสัยเกี่ยวกับการแต่งตัวไปดูบ้าน. Pantip. (n.d.). Retrieved November 25, 2021, fromhttps://pantip.com/topic/32537797.

39. ห้ามพลาด!

Cha

Eunพooตอกกลับ ไอดอลสาวหลังถูกชวนออก

เดท: Daradaily. www.daradaily.com. (n.d.).

Retrieved November 25, 2021, fromhttps://ftp.daradaily.com/news/71563/r ead.

How to cite this article: Thanupran $\mathrm{T}$, Amphichaluay P, Phlailaharn P. The correlational study of the influence of mass media on one's self-satisfaction. International Journal of Science \& Healthcare Research. 2021; 6(4): 320-334. DOI: https://doi.org/ 10.52403/ijshr.20211045 